\title{
Optimization of radiogram thresholding procedure
}

\section{Optymalizacja procedury progowania radiogramów}

\begin{abstract}
This study deals with the automated segmentation of radiographic pictures, which is an important task in the process of automatic weld defect recognition. Generally, the process of radiogram binarisation is controlled by several parameters, the selection of which is a very demanding task that strongly influences the overall results. This paper presents an algorithm for an automatic selection thresholding method as well as its parameters using genetic programming techniques. The proposed method could be applied as part of the industrial process of automatic radiogram analysis.
\end{abstract}

\section{Streszczenie}

Praca porusza zagadnienia związane z procesem automatycznej obróbki i analizy cyfrowych zdjęć radiograficznych połączeń spawanych. W pracy zaprezentowano metodę doboru parametrów progowania zdjęć radiograficznych celem ekstrakcji obiektów potencjalnych niezgodności spawalniczych. Dobór optymalnych parametrów procedury progowania dokonywany jest za pomocą techniki programowania genetycznego.

\section{Introduction}

Radiography is an important part of modern non-destructive testing. Its technical applications focus mainly on but are not limited to, the assessment of the quality of metal parts and their connections. The greatest drawbacks of digital radiography are related to time and cost. Radiographic image acquisition itself is relatively fast and moderately expensive; the problem lies in the process of the search for and classification of defects. An apparent solution to this problem is the creation of computer tools aimed at supporting or even superseding the radiologist in their work. Some such solutions have already been proposed but those cover mostly specific tasks [1] and rarely the more difficult or general cases $[2,3]$.

dr inż. Piotr Baniukiewicz - Zachodniopomorski Uniwersytet Technologiczny w Szczecinie

\section{Problem statement}

The importance of systems that support or even supersede radiologists, such as automatic radiogram analysis systems or automatic defect recognition systems, is growing. Nevertheless, the process of automatic defect recognition (ADR) in radiography is very complicated owing to the nature of the defects. Possible imperfections located in the weld line are mostly small, very subtle, with low contrast or sharpness and generally, they are barely visible.

Moreover, there are many additional objects located in the picture, such as image quality indicators or technological marks that could easily disturb the detection of imperfections owing to their higher intensity. The process of radiogram analysis is completely intuitive for an experienced operator but for a computer, it can be a very demanding task encompassing the fields of image analysis, object recognition and computer vision. A typical computerised system for ADR follows the process described in Figure 1. The most important part of radio- 


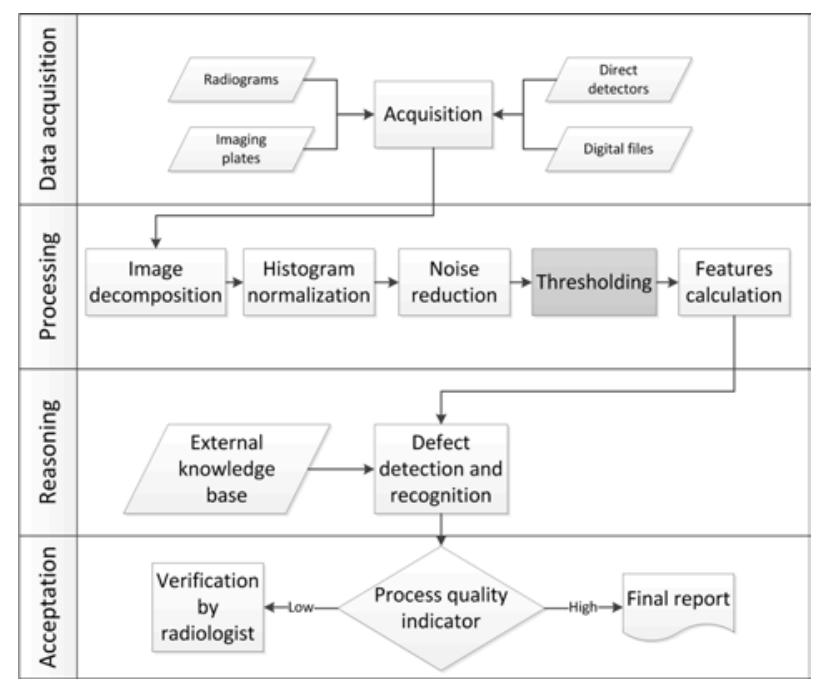

Fig. 1. General process flow of automated weld defect recognition systems. Grey box stands for the stage under consideration in this paper. Rys. 1. Proces automatycznej analizy radiogramów. Kolorem szarym zaznaczono etap analizowany w publikacji

gram processing is defect segmentation. This process has crucial meaning for the reliability and effectiveness of the automated system. Several methods could be used to separate defects from the background, ranging from fast and simple segmentation methods, such as thresholding, to more advanced methods that combine background subtraction and low-pass filtering [4] or morphological operations.

\section{Proposed methodology}

A segmentation method represented by a chain of selected thresholding algorithms and post-processing operations has been proposed. Over one hundred digital radiograms were collected. After analysis by a proficient radiologist, they were used to find the best way of segmenting radiographic images in an optimization process. The genetic programing technique was used to evaluate the optimal radiogram processing chain and additionally, possible practical applications of the proposed methodology are discussed.

Genetic programming (GP) [5] is an automated methodology inspired by biological evolution to find computer programs that best perform a user-defined task. GP is a machine-learning technique that uses an evolutionary algorithm to optimise a population of computer programs, according to a fitness landscape determined by a program's ability to perform a given computational task. GP is a branch of genetic algorithms. GP creates computer programs as the solution. The computer programs evolved by GP are composed from genes and they have the form of a tree-like structure. There are two types of genes: functions and terminals. Terminals, in tree terminology, are leaves (nodes without branches), whereas functions are nodes with children. Commonly, the function's children provide the arguments for the function. The connections among nodes, as well as among functions and their terminals, are subject to modification at every iteration of the algorithm until the desired quality of solution is obtained.

\section{The structure of genetic programming}

There were five operations permitted in the radiogram processing chain; two thresholding methods such as those of Sauvola and Niblack and three post-processing methods, such as erosion (E), dilation (D) and median filtering $(\mathrm{M})$. The main role of median filtering was to remove binary noise and standalone pixels that remained after thresholding. Therefore, the size of the median window was relatively small, i.e., not exceeding seven. Such functions were combined in any order by the GP algorithm forming the radiogram processing chain. The recurrent appearance in the chain of any of these functions, except thresholding, was allowed. The maximal length of the processing chain was set to 12 functions but the resulting chain obtained in the optimisation process could be shorter. The parameters (terminals) of every operation in the processing chain were selected by GP within the defined bounds. The thresholding operation was supposed as the first operation in the processing chain.

Error Measure. The most difficult and most important concept of GP is the fitness function. This determines how well a program is able to solve the problem. For the considered problem, this means the quality of the thresholding of the radiograms forms a training set obtained for a single processing chain (individual). The process of image thresholding can be considered as a binary classification process in which the outcomes are labelled as either positive $P$ (pixel of imperfection) or negative $\mathrm{N}$ (pixel of background). For such a settled problem, the most convenient way to measure the performance of an individual is to use indicators related to the Receiver Operating Characteristic (ROC) curve analysis. The performance of the given processing chain was measured using the Matthews correlation coefficient (MCC), which is used in machine learning as a measure of the quality of the binary classifications. It takes into account the true and false positives (TP, FP) and negatives (TN, FN) and it is generally regarded as a balanced measure, the use of which is intended for classes of very different sizes.

$$
M C C=\frac{T P \cdot T N-F P \cdot F N}{\sqrt{(T P+F P)(T P+F N)(T N+F P)(T N+F N)}}
$$

\section{Results and discussion}

The algorithm ran for 35 test radiograms and finished after 40 iterations. The initial population of individuals (processing chains in this case) in GP is generated in 
a random way, which implies that the initial value of $\mathrm{MMC}$ is near 0 . In further generations, the performance of segmentation increases as a result of the evolution of the processing chain structure. The best processing chain obtained in this process for the analysed data is presented in Table 1. Several interesting observations can be made by analysing the best chains obtained from multiple experiments. The median filtering appears in most cases at the end of the chain, which seems to be logical. Dilation and erosion appear in series and they tend not to interleave. Thus, the importance of complex morphological operators, such as opening and closing is less significant in this process than basic eroding or dilating.

Exemplary results are presented in Figure 2.

For the entire set of images, the POD and PFA coefficients were evaluated globally and they equalled 0.61 and $5 e^{-4}$, respectively. The final decision on object
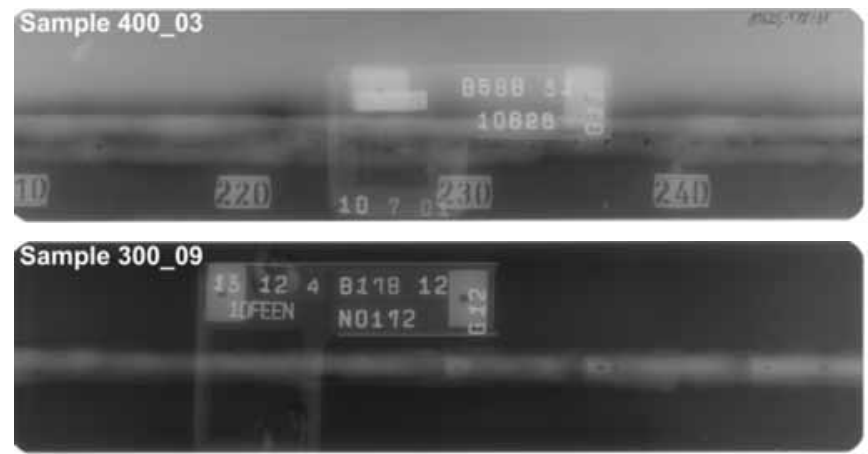

Table I. The best processing chain obtained by means of GP optimisation Tablica I. Optymalny łańcuch przetwarzania radiogramu uzyskany w wyniku optymalizacji GP

\begin{tabular}{|c|c|c|c|l|c|}
\hline No & Function & Terminal & No & Function & Terminal \\
\hline 1 & $\mathrm{~T}_{\mathrm{s}}$ & $\begin{array}{c}23 \\
0.0203\end{array}$ & 7 & Erosion & 3 \\
\hline 2 & Erosion & 2 & 8 & Erosion & 1 \\
\hline 3 & Dilation & 2 & 9 & Erosion & 2 \\
\hline 4 & Dilation & 2 & 10 & Median & 3 \\
\hline 5 & Dilation & 1 & 11 & Median & 1 \\
\hline 6 & Dilation & 1 & & & \\
\hline
\end{tabular}

classification is taken in the subsequent steps. Thus, a $100 \%$ efficiency in this stage of the processing is not expected.
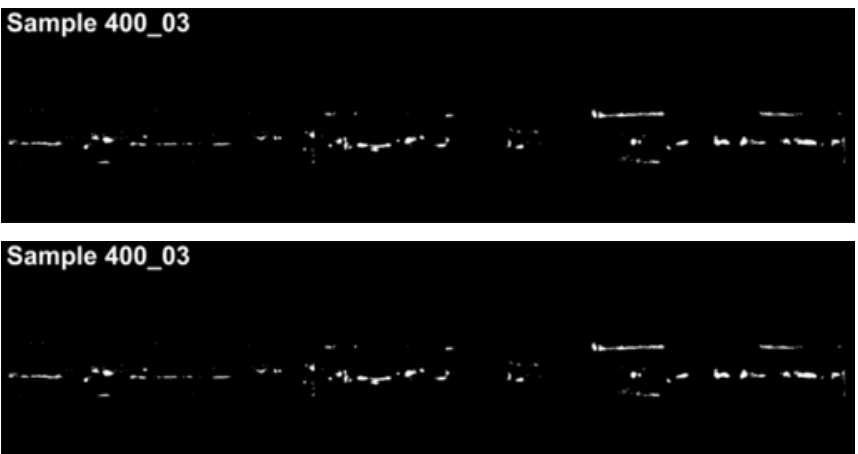

Fig. 2. Exemplary results of radiogram thresholding using optimised processing chain.

Rys. 2. Przykładowe wyniki progowania radiogramów przy pomocy optymalnego łańcucha operacji.

\section{Conclusions}

The obtained results prove the usability of this method in practical applications. The optimisation of the thresholding process can improve automatic or semi-automatic defect detection systems. The proposed algorithm can be applied for industrial radiograms taken within the same process and under the same conditions. Any change of the process that influences the gradient of radiogram luminance will require the revising of the optimisation results. However, this is not a disqualifying drawback, because in industrial applications, the number of radiograms taken within the same process could run into thousands.

\section{References}

[1] da Silva, R.R., et al., Evaluation of the relevant characteristic parameters of welding defects and probability of correct classification using linear classifiers, Insight, 2002. 44(10): p. 616-622.

[2] Mery, D., et al., Fully automated X-ray inspection. Non-destructive testing in industrial applications, Materialprufung, 2001. 43(1112): p. 433-441.

[3] Sikora, R., et al., Intelligent System for Radiogram Analysis, Review of Progress in Quantitative Nondestructive Evaluation, Vols 30a and 30b, 2011. 1335: p. 525-532.
[4] Sikora, R., et al., Comparison of selected weld defect extraction methods, Review of Progress in Quantitative Nondestructive Evaluation, Vol 27a and 27b, 2008. 975: p. 1034-1041.

[5] Koza, J.R., Genetic programming : on the programming of computers by means of natural selection. Complex adaptive systems. 1992, Cambridge, Mass.: MIT Press. 